\title{
HOUSING HETEROGENEITY DIMENSIONS AND THEIR ELEMENTS: A SYSTEMIC APPROACH
}

\author{
Jānis VANAGS ${ }^{1}$, Ineta GEIPELE ${ }^{2}$, Auseklis SARKANS ${ }^{3}$, \\ Didzis USENIEKS ${ }^{4}$ \\ 1,2,4 Riga Technical University, Latvia \\ ${ }^{3}$ Real Estate Investment Consultation Agency "Verus Investment", Latvia \\ Corresponding author e-mail: Janis.Vanags@rtu.lv
}

\begin{abstract}
Housing market participants constantly face the housing heterogeneity the technical and socio-economic differences of dwellings in a certain populated area. Housing heterogeneity often complicates the managerial decision making related to housing transactions, identification and objective evaluation of the quantitative and qualitative aspects of transactions. Housing heterogeneity is an objective phenomenon that implies housing uniqueness - housing distinguishing characteristics divided into specific and interconnected groups within the framework of the research. Most of these differences can be noticed by each market participant, but some of them can be identified only by experienced and professionally trained market participants. Theory and practice have demonstrated that the constituent groups of heterogeneity influence each other and take part in the formation of market value and transaction price of housing units. The increased housing construction intensity, the continuous modernisation of construction technologies and the diversification of building materials used in housing construction, as well as restriction of the building plot of land change the quantitative and qualitative aspects of heterogeneity dimensions. This poses considerable challenges to market participants in the managerial decision making process related to housing transactions. Research results demonstrate that the socio-economic elements of housing heterogeneity are constantly changing under the influence of the dominating factors of the external and internal environment. Therefore, nowadays, housing heterogeneity has become a major cause of information asymmetry, which means that heterogeneity is inherent in the formation of socio-economic market barriers in the housing market.
\end{abstract}

Keywords: Housing heterogeneity, housing heterogeneity dimensions, housing market, systemic approach.

\section{INTRODUCTION}

Topicality of the research is closely related to the relatively high price volatility in the housing market in the medium term and the identified violations of the laws and regulations in housing transactions. In all countries of today's globalised world, the housing market functions within the framework of regulated market economy, the development of which is constantly monitored by the respective state 
authorities, if necessary, to take preventive and/or corrective measures in order to limit or activate the market participants' activities. The research results show that the impact of state institutions on the factors contributing to the growth of housing prices in various EU and other countries is quite different. There is significant growth in a few years of housing price difference among EU countries laying in the same global economical system and under the influence of related environmental factors.

Housing valuation process as a type of entrepreneurship is constantly related to the awareness of housing heterogeneity dimensions and the forecast of their possible changes. Unfortunately, in the valuation practice of real estate valuation, heterogeneity is given insufficient attention, despite the fact that the awareness of quantitative and qualitative effects of housing heterogeneity is the valuation function and the market value of housing unit is the result of the valuation function. In the current standard, past and future dimensions are not balanced; too much attention is devoted to the heterogeneous elements formed in the past, and too little attention is devoted to heterogeneity dimensions and their elements that are vulnerable when they are confronted with socio-economic events in future.

In fact, the property valuation standards and the relevant professional activities are heterogeneity causes of property, including housing units. Thus, by means of actions involved in the valuation process, significant heterogeneity dimensions are identified to give market participants the most objective view of the constituent elements of real estate market price that could facilitate managerial decision making related to the process of entering into transactions. The research results demonstrate that in the valuation practice, a dominating approach is the mechanical one that is used to determine the market value of housing units, and possible changes in price are suppressed in the short and medium term, which is an essential aspect of market participants in the managerial decision making in relation to housing transactions. Unfortunately, in practice, valuators pay attention only to the individual dimensions of heterogeneity, and often they are perceived and analytically evaluated in isolation from each other without realising that they are different heterogeneous elements of one system. The interaction of these elements with each other and with the external environment determines the price of a particular housing unit.

The global financial crisis, its causes and changes in housing prices in the postcrisis period clearly show the shortcomings of the valuation standard and its adaptation with regard to heterogeneity characteristic of property units. These issues have come to the attention of the World Association of Valuation Organisations and the International Valuation Standards Council. The current standard focuses solely on certain heterogeneity dimensions and their constituent elements, and it lacks a systemic approach, which to a great extent is consistent with the global challenges and may give market participants a clearer view of not only the market value of housing units but also of changes at least for the next few years.

\section{GOAL OF THE RESEARCH AND METHODOLOGY}

In view of the topicality of the theme, the following goal of the research has been set: 
within a systemic approach to identify the constituent dimensions of housing heterogeneity and the elements of quantitative and qualitative aspects that determine the market value of housing units and are used for managerial decision making in relation to housing market transactions.

The research methodology consists of a set of mutually compatible and complementary research methods, in which the central place is taken by a systemic approach methodology. To identify the objective aspects of housing heterogeneity, the observation, comparison, analysis and synthesis methods as well as deductive and inductive methods have been used. Using these methods, the constituent dimensions of housing heterogeneity are identified and the objective elements determining the content of these dimensions are revealed. For the analytical assessment of scientific articles relevant to the research topic, the deduction, comparison, analysis and logical access methods have been used.

The object of the research is housing heterogeneity; the subject of the researchdimensions of housing heterogeneity, their most important elements that are studied within a systemic approach.

To reach the goal of the research, a wide range of scientific information has been used. Scientific and research issues about the housing market, the total supply and demand, the price levels, and their contributing factors have come to the attention of scientists in many countries in the 20th century. During this time, European and other countries in the world faced enormous shocks that significantly affected housing availability for many millions of citizens. The studies were updated by the 2008 global housing crisis, which forced to postpone plans and to improve the living conditions for many households in many countries and continents. Exactly the last global crisis forced policy-makers, researchers and practitioners to change their views on the housing market shortcomings, preventive measures, real estate market-specific information asymmetry and housing market value, which did not meet global challenges.

\section{HOUSING HETEROGENEITY IN SCIENTIFIC RESEARCH - EVALUATION OF ACADEMIC INFORMATION}

Heterogeneity of market elements attracted the attention of economic researchers in the second half of the 20th century. One of the pioneers in this research area is Shervin Rosen (Rosen, 1974), who devoted his attention to the differences among market participants in relation to their effect on prices in the housing market characterised by incomplete opportunities for replacement of goods with alternatives required by the buyer. On the basis of the fundamental methodological principles of heterogeneous object exploration developed by Shervin Rosen (Rosen, 1974), Tony O'Sullivan (O’Sullivan \& Gibb, 2008) developed the hedonic price model to determine rental income. This model incorporates a number of housing heterogeneous elements such as housing constructive dimension, neighbourhood characteristics and location. Koopman (2012), in turn, used the research results by Shervin Rosen (Rosen, 1974) in order to develop a more detailed hedonic price model comprising housing quality characteristics as a "bundle of attributes" related to the constituent elements of 
housing heterogeneity. Unfortunately, the above-mentioned models lack a systemic approach to the constituent dimensions of housing heterogeneity, factors contributing to their quantitative and qualitative aspects, as well as to mutual interaction, which is the most important function forming the market value and the price of a housing unit. Thus, the hedonic price models used in practice do not provide an opportunity to include all dimensions of housing heterogeneity in the price.

Table 1. Studies on the Housing and/or Housing Market Heterogeneity (table developed by the authors on the basis of the research results)

\begin{tabular}{|c|c|c|}
\hline $\begin{array}{l}\text { Dimensions of } \\
\text { heterogeneity }\end{array}$ & Elements of heterogeneity & Authors \\
\hline \multirow{3}{*}{$\begin{array}{l}\text { Technical } \\
\text { dimension }\end{array}$} & Housing buildings & $\begin{array}{l}\text { Castellano et al. (2016), } \\
\text { Seinre et al. (2014), etc. }\end{array}$ \\
\hline & $\begin{array}{l}\text { Social infrastructure } \\
\text { and accessibility }\end{array}$ & $\begin{array}{l}\text { Agarwal et al. (2016), } \\
\text { Haurin and Brasington (1996), } \\
\text { Huh and Kwak (1997), etc. }\end{array}$ \\
\hline & Housing energy efficiency & $\begin{array}{l}\text { Ayala et al. (2016), } \\
\text { Marius and Claus (2016), } \\
\text { Balta-Ozkan et al. (2014) }\end{array}$ \\
\hline \multirow{3}{*}{$\begin{array}{l}\text { Economic } \\
\text { dimension }\end{array}$} & $\begin{array}{l}\text { Income of households and } \\
\text { occupation of home owner }\end{array}$ & $\begin{array}{c}\text { Haurin and Brasington (1996), } \\
\text { Koopman et al. (2012) }\end{array}$ \\
\hline & Housing prices & $\begin{array}{c}\text { Wen and } \mathrm{He}(2015) \\
\text { O’Sullivan and Gibb (2008) }\end{array}$ \\
\hline & Housing supply and demand & $\begin{array}{c}\text { Koopman et al. (2012), Kurlat (2015), } \\
\text { Lindbergh and Wilson (2016) }\end{array}$ \\
\hline \multirow{5}{*}{$\begin{array}{c}\text { Social } \\
\text { dimension }\end{array}$} & $\begin{array}{l}\text { Housing affordability } \\
\text { and unemployment }\end{array}$ & $\begin{array}{c}\text { Reed and Ume (2016), } \\
\text { Swinkoski (2012), Hernandez (2016) }\end{array}$ \\
\hline & $\begin{array}{l}\text { Neighbours and } \\
\text { neighbourhoods }\end{array}$ & $\begin{array}{c}\text { Koopman et al. (2012), Heijden (2013), } \\
\text { O'Sullivan and Gibb (2008) }\end{array}$ \\
\hline & Information asymmetry & Koopman et al. (2012) \\
\hline & Crime & $\begin{array}{c}\text { Whittaker et al. (2016), Garth (2006), } \\
\text { De Ayala, Galarraga and Spadaro } \\
\text { (2016) }\end{array}$ \\
\hline & Racial and ethnic aspects & Voborníková (2014) \\
\hline \multirow{3}{*}{$\begin{array}{l}\text { Governance } \\
\text { dimension }\end{array}$} & Housing management & $\begin{array}{c}\text { Gao and Ho (2016), Gao and Chen } \\
\text { (2016), Clapham, Franklin } \\
\text { and Saugères (2000) }\end{array}$ \\
\hline & State housing policy & $\begin{array}{l}\text { Lindbergh and Wilson (2016), } \\
\text { White (2016), Hanlon (2015), } \\
\text { Posey (2016) }\end{array}$ \\
\hline & $\begin{array}{l}\text { Management of home } \\
\text { owners and stakeholders }\end{array}$ & $\begin{array}{c}\text { Gao and Chen (2016), } \\
\text { Heitel et al. (2015), Yau (2013), } \\
\text { Geipele and Slava (2012) }\end{array}$ \\
\hline \multirow[t]{2}{*}{$\begin{array}{l}\text { Environmental } \\
\text { (ecological) } \\
\text { dimension }\end{array}$} & $\begin{array}{l}\text { Ecological sustainability } \\
\text { and housing }\end{array}$ & $\begin{array}{c}\text { Gustavsson and Elander (2016), } \\
\text { Dezhi et al. (2016), Castellano et al. } \\
(2016)\end{array}$ \\
\hline & Housing waste & $\begin{array}{l}\text { Dezhi et al. (2016), Peterson et al. } \\
\text { (2013), Castellano et al. (2016) }\end{array}$ \\
\hline
\end{tabular}


The different dimensions of housing heterogeneity have become relatively popular in the academic environment. Various aspects of these dimensions have attracted the attention of scientists all over the world. Table 1 summarises the latest and most important studies on the quantitative and qualitative aspects of the dimensions of housing heterogeneity, which is only a small part out of the multitude of the studies related to this theme. However, it is sufficient to get an idea of the dimensions of housing heterogeneity and their relationship with the market value and the transaction price of a housing unit. The research results demonstrate that in the scientific environment, the social, technical and economic dimensions are the most popular ones, and less attention is devoted to the governance and ecological dimensions.

To investigate the socio-economic dimensions of housing heterogeneity and their interaction with the external environment, it is important to study the biggest housing bubble over the past decade and the subsequent global financial crisis. These issues have attracted the attention of De Vries $(2010)^{1}$, Wassenberg $(2013)^{2}$, and other researchers. In European countries, an important role is played by Hoekstra's study $(2010)^{3}$, which reveals the housing market heterogeneity in European countries and the market response to the global crisis. In these studies, a priority area is given to the dominating factors of the external environment and their impact on the individual constituent elements of housing heterogeneity, their quantitative and qualitative changes. For the investigation of static and dynamic housing systems, it is worth mentioning Van der Heijden's study (2013) ${ }^{4}$, which distinguishes the static housing system from the dynamic one. However, such a housing system classification plays rather a symbolic and deterministic role. In fact, any housing system is a type of system created by individuals; all such systems are heterogeneous and dynamic - their quantitative and qualitative composition changes as a result of the interaction of internal elements of the system, as well as through interaction of those elements with the external environment of the system a higher-level social system. Van der Heijden (2013) also recognises that economic recession affects the statistical housing system, i. e., by reducing the number of transactions, new housing construction volumes reduce.

\section{HOUSING HETEROGENEITY AND ITS OBJECTIVE NATURE}

In real estate economics, housing heterogeneity is a relatively new concept. In various studies on the housing market in order to explain price differences of outwardly similar housing units, such terms as "housing uniqueness", "housing differences", "housing location in relation to price", and similar are often used. Shortcomings of these concepts are determined by the fact that they do not reveal

\footnotetext{
${ }^{1}$ De Vries, P. 2010. Measuring and Explaining House Price Developments.

${ }^{2}$ Wassenberg, F. 2013. Large Housing Estates: Ideas, Rise, Fall and Recovery.

${ }^{3}$ Hoekstra, J. S. C. M. 2010. Divergence in European Welfare and Housing Systems. Amsterdam. IOS Press. ISBN:13 - 978-1-607-506-676.

${ }^{4}$ Van Der Heijden, H. 2013. West European Housing Systems in a Comparative Perspective.
} 
the constituent dimensions of housing differences and the relation of their composition to the market value and transaction price of a housing unit.

For the above reasons, within the framework of the present research, instead of housing uniqueness and differences, the term "housing heterogeneity" has been used, which fully reveals differences in the technical, economic and social dimensions of each housing unit and the objective nature of the formation of these differences. Within the framework of the research, the term "housing heterogeneity" is explained as follows:

housing heterogeneity - a set of technical, governance, socio-economic and ecological differences in housing used in the formation of the market value of housing units, determining the transaction price.

In every explanation of the concept, it is possible to identify the scientifically and practically most important elements that determine the essential features of the definable object. Then, the scientifically most important element of housing heterogeneity is a set of differences, the structure of which consists of technical, governance, socio-economic and ecological differences of each housing unit. Moreover, the origin of these differences is an objective one, which in the framework of the research is considered to be an important aspect, but in the managerial decision making it is often ignored. The subsequent sections of the paper reveal the constituent elements that determine the impact of each set of differences on the formation process of the market value and transaction price of a housing unit.

Within the framework of the research, the following sets or dimensions of differences forming the housing heterogeneity have been revealed:

a) differences in the technical dimension,

b) differences in the social dimension,

c) differences in the economic dimension,

d) differences in the residential building governance dimension,

e) differences in the ecological dimension.

The research results demonstrate that the constituent dimensions of housing heterogeneity are interrelated and the interaction effect is observed in the market value and transaction price of each housing unit.

Using a systemic approach method, the housing heterogeneity model has been developed that demonstrates the constituent dimensions of quantitative and qualitative aspects of heterogeneity. One of them is related to ecology. Within the framework of the research, the concept "ecology" is not used as a science that deals with the relationships among the groups of living things and their environment ${ }^{5}$. In the present research, the term under discussion refers to the natural environment created by the impact of human activity, which as a unique formation deals with a plot of land envisaged for housing construction, affects the tenants' state of health and recreational conditions, as well as participates in the market value formation of a residential building in a particular place and time.

Figure 1 demonstrates the housing heterogeneity model developed by the authors of the research.

\footnotetext{
${ }^{5}$ Merriam-Webster Dictionary-. Quad Graphics, 2015. Martinburg. ISBN 978-0-87779-295-6.
} 


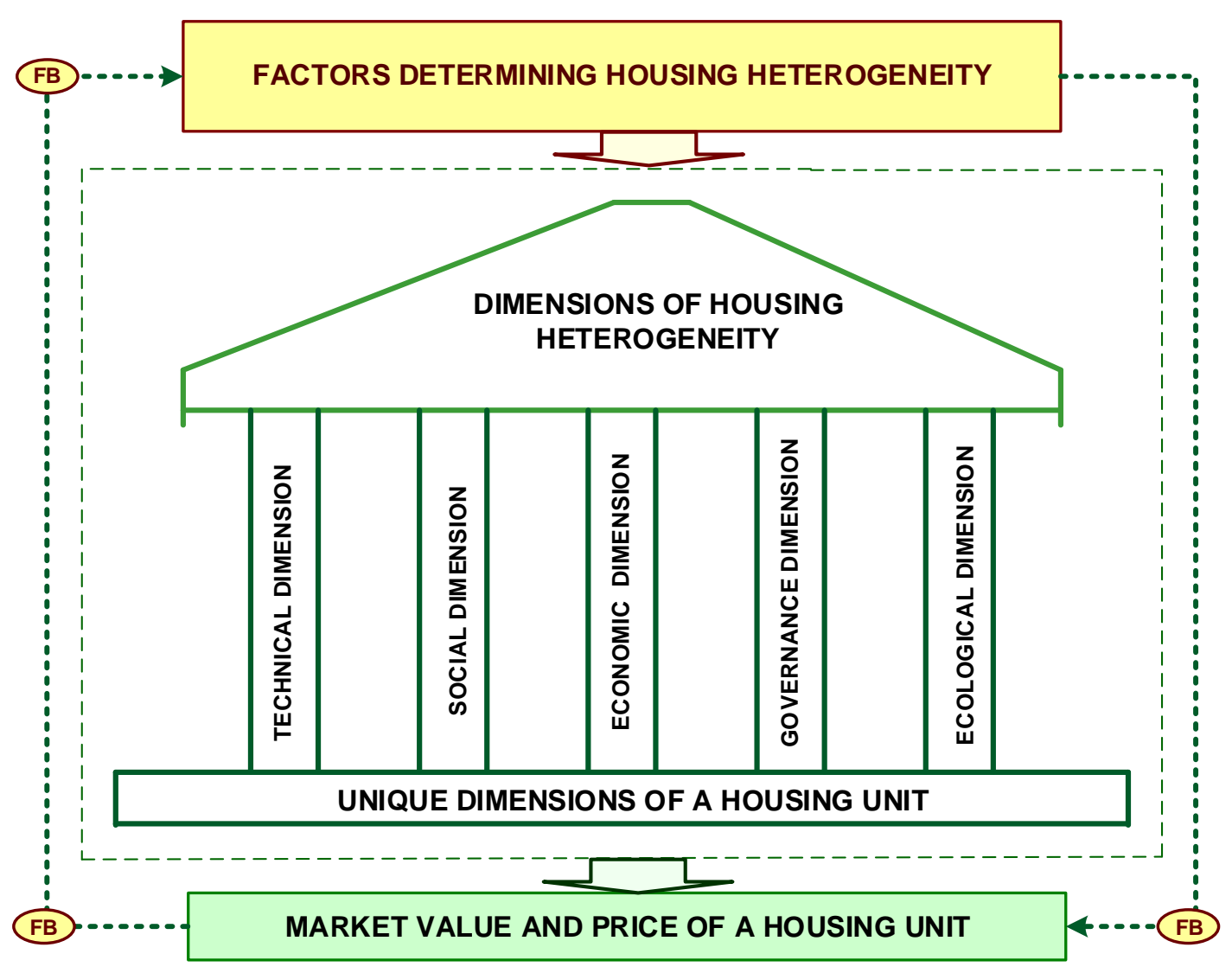

Fig. 1. Constituent dimensions of housing heterogeneity and their relation to the market value of housing uniāts (Figure developed by the authors).

It is seen that a housing unit and heterogeneity dimensions forming its uniqueness comprise the socio-economic and technical system, the elements of which are formed by the quantitative and qualitative aspects of heterogeneity dimensions. The constituent dimensions of housing heterogeneity are closely related to each other and form the values characteristic of each housing unit, which are combined in the use value and working life. These dimensions of heterogeneity form as a result of the interaction of several subjects and environment. They affect each other and determine the living conditions of the tenants of a residential building, as well as participate in the formation of the market value of a residential building.

The most important elements of the technical dimension of heterogeneity are as follows:

- location and geographical coordinates of a residential building;

- building area and the adjacent area of a residential building;

- metric units of the quantitative dimensions of a residential building;

- architectural form and structural elements of a residential building, the conformity of their performance with the technical requirements and the depreciation rate;

- technical support of the energy resource supply of a residential building; 
- energy and water consumption of a residential building divided into the types of resources and apartments;

- operational energy losses in a building, etc.

The most important elements of the social dimension of heterogeneity are as follows:

- demographic and ethnic composition of the tenants of a residential building;

- mental capacity of the tenants of a residential building, effects of its manifestation, and side effects in relation to building operation and management;

- attitude of the tenants of a residential building towards laws and regulations the level of legal consciousness;

- moral characteristics of the tenants of a residential building - structural division by the major categories of morality;

- participation of the tenants of a residential building in self-organised cultural and entertainment events, as well as other elements.

The most important elements of the economic dimension of heterogeneity are as follows:

- economic interests of the tenants of a residential building, forms of their manifestation in building operation and management;

- resources required for residential building management, their quantitative and qualitative composition;

- resources required for residential building operation and management, their quantitative and qualitative composition;

- conformity of internal and external resources required for residential building management;

- prices of resources consumed for the management of a residential building, the nature and tendency of these changes;

- participation of the tenants of a residential building in the financing of building management - payment amount, regularity, and other elements.

The most important elements of the governance dimension of heterogeneity are as follows:

- non-governmental organisations established for residential building selfmanagement;

- participation of the tenants of a residential building in decision making related to building operation and management;

- tenants' adherence to the procedure stipulated by a self-government body in relation to the operation and management of a residential building and its adjacent territory;

- security system of a residential building, and tenants' participation in its creation, maintenance and development;

- approval procedure of residential building management budget, supervision of budget outturn, as well as other elements. 
The most important elements of the ecological dimension of heterogeneity are as follows:

- positive and negative effects and side effects posed by building operation and management, their impact on the environment;

- the total volume of waste generated by building operation and management and its structure, waste interaction with the environment;

- the amount of resources necessary for domestic waste disposal and qualitative composition;

- authorised and/or unauthorised influence of tenants on the green spaces adjoining the residential building and neighbourhood - flora and fauna;

- voluntary participation of the tenants of a residential building in the flora and fauna conservation and propagation in the adjoining green space and/or neighbourhood.

The above-mentioned dimensions of housing heterogeneity and their constituent elements may give the stakeholders a sufficiently detailed picture of the housing uniqueness and the constituent elements of uniqueness. It is important to realise that the dimensions of heterogeneity and their constituent elements interacting with the factors of external environment cause the quantitative and qualitative effects that participate in the formation of the price of housing units and the determination of the market value of housing units.

Observation results of market participants' behaviour demonstrate that satisfaction of needs is closely related not only to material needs but also to spiritual needs. The quantitative and qualitative aspects are determined by each individual's characteristic knowledge, skills, set of moral and material values as well as ethical principles and other elements of social significance. Therefore, for housing market participants, not only the housing technical dimension - location, basic construction dimensions, and architectural form - is of importance, but also the spiritual dimension, which involves the social, governance and ecological dimensions.

The market value and sell price of housing units are determined not only by changes in the external environment, which are reflected in the interaction of market participants that create the total demand and total supply of the housing market. Osland and Thorsens (Osland, Thorsen, I. S., \& Thorsen, I., 2016) have studied the significance of the local spatial aspects in the formation of heterogeneity of housing market, but Rubio (Rubio, 2014) focused on the peculiarities of the housing heterogeneity in the monetary union of EU.

The changes in the market value of a particular housing unit are determined by the quantitative and/or qualitative aspects of the dimensions of housing heterogeneity, which are constantly influenced by the interaction of these dimensions, as it is shown in Figure 2.

Figure 2 demonstrates the interaction links of the constituent dimensions of housing heterogeneity. This interaction leads to a variety of positive and negative effects that influence the price of a respective housing unit. For example, the construction works carried out to reduce the heat losses of a residential building will contribute to the increase in the market value of a respective housing unit, but tenants' negligent attitude towards the defects resulted from building operation leads to a decrease in the market value. Changes in the sell price of a respective 
housing unit in a particular area in a given period of time determine the interaction of the factors of external environment with the constituent elements of housing heterogeneity. The research results demonstrate that changes in the external environment have a greater impact on the price of housing units in comparison with the impact exerted by housing internal environment.

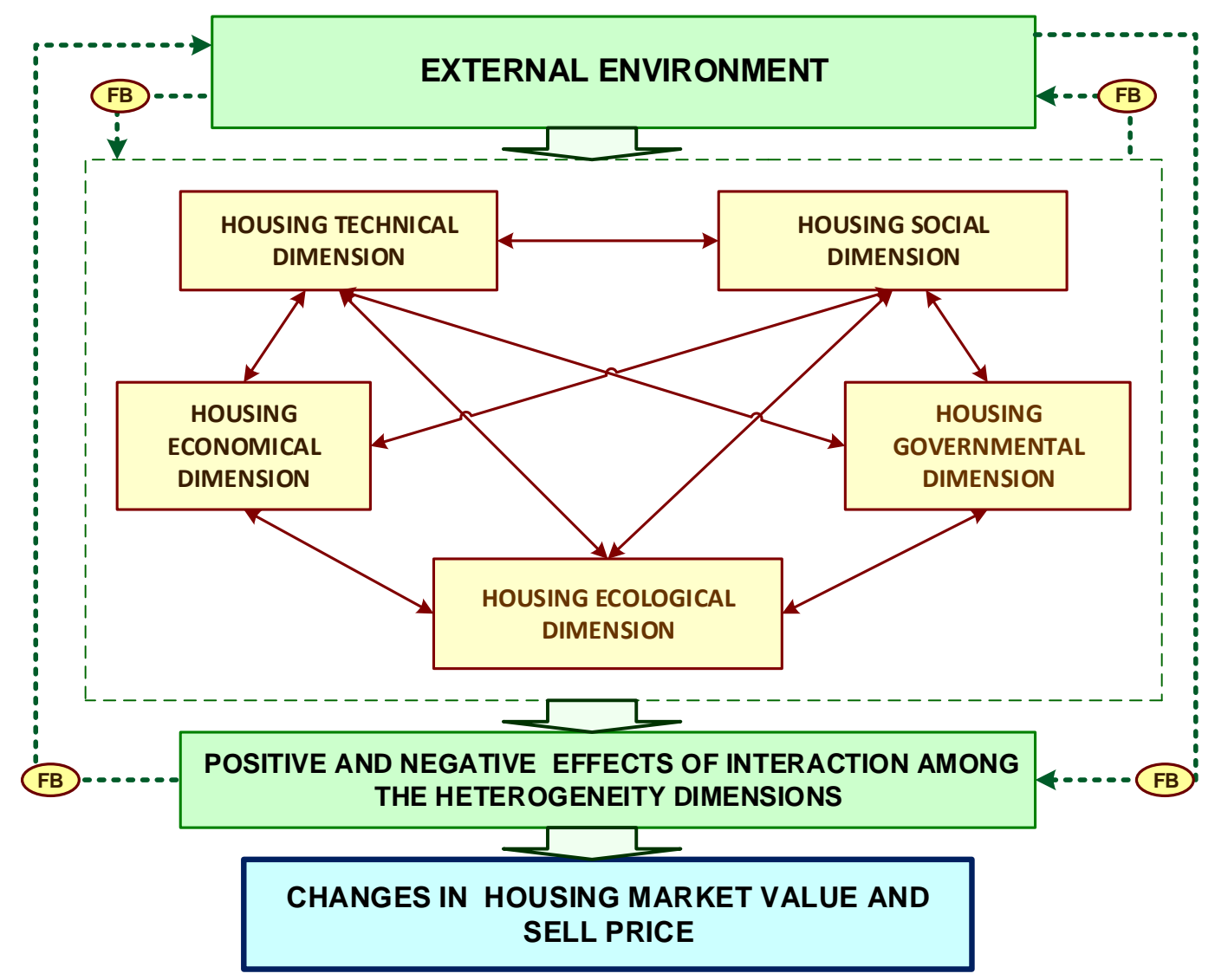

Fig. 2. The model of the effects of the interaction among the constituent dimensions of housing heterogeneity (Figure developed by the authors).

In the process of determining the market value of housing units, it is important to take into account the changes in the quantitative and qualitative aspects of the dimensions of housing heterogeneity, the positive and negative effects of their interaction, as well as the changes in the external environment and their impact on the possible sell price of a housing unit. Such an approach can reduce the information asymmetry among market participants forming the housing demand and supply (Koopman et al., 2012). Information asymmetry is one of the most important social dimension elements of housing heterogeneity, which greatly contributes to the rapid increase in the price of housing units. The cause of this phenomenon is often related to uncertainty among households about the price of housing units and the changes in price within one- and several-year period. 


\section{PRACTICAL ASPECTS OF HOUSING HETEROGENEITY}

The evidence provided in the present research about housing heterogeneity, its constituent elements, origin and the objective nature creates a sufficient scientific basis for the relation of market price of housing units with the quantitative and qualitative aspects of the constituent dimensions of homogeneity. Determining the market value of housing unit in practice, the technical and economic dimensions are usually evaluated. In many cases, it is quite enough to find buyers for housing units on sale who agree to enter into a transaction agreement at a price that is not significantly different from the market value determined by means of calculations. However, it does not mean that the market value would remain constant if in the evaluation process of a particular housing unit the necessary attention were given to other dimensions of housing heterogeneity to reveal aspects that increase/decrease the market value. For example, neighbours have a major impact on socio-psychological aspects and governance aspects affecting the quality of life in a residential building or in single-family neighbourhoods (Cervero and Duncan, 2004; Koopman et al., 2012; O'Sullivan and Gibb, 2008), but in the valuation practice it is ignored. In practice, it is often observed that buyers agree to pay a higher price in cases when they make sure that the neighbour meets their expectations of a "good neighbour". Conversely, among sufficiently informed and knowledgeable buyers it will be difficult to sell a housing unit at a market value if the buyers" opinions on a "desirable or good neighbour" differ in this important matter. In addition, good neighbourly relations are an essential safety aspect of the living environment, as well as an important catalyst for creating, satisfying and developing tenants' spiritual and/or material interests.

In the age of the intensification of the urbanisation process, the environmental or ecological dimension plays an important role in the formation of the market value of housing units; however, it is still largely ignored. In the process of determination of the market value of housing units, air pollution in a particular area is not taken into account, the quantitative and qualitative aspects of pollution are not revealed, and the noise level created by urban transport infrastructure and its changes in different seasons and time of day are not identified.

Many buyers pay attention to the governance of the respective residential building and its adjacent area. The tenants of a residential building highly evaluate the established practice and tradition of building management, starting with budgeting and ending with the collection of payments for the resources consumed by tenants. Thus, the building manager and self-government bodies affect the working life of the building and the use value, which should take part in the formation of the market value of housing units and in the determination of the transaction price. However, this happens only in cases when the residential appraiser - the market value appraiser - pays attention to these issues and does everything possible to include governance effects and side effects of the residential building and the adjacent area in the market value. 


\section{CONCLUSION}

The dimensions of housing heterogeneity and their constituting elements identified within the framework of the research are an important aspect of the conformity of the market value to the actual value of a certain type of the residential building located in a particular place, taking into account both positive and negative effects and side effects of the heterogeneity dimensions. It is important to note that buyers entering into housing transactions purchase not only material things necessary for satisfying their basic needs, but also a particular place of residence with its characteristic governance, social and ecological side effects, which largely participate in the formation of heterogeneity of the purchased dwelling and affect its price. However, this important conclusion is ignored in the valuation standard and market valuation practice.

The dimensions of housing heterogeneity and their most important elements revealed in the framework of the research can be used to develop the housing hedonic price index model, as well as elaborate the housing market valuation methodology. The socio-economic causes of the global housing crisis are closely related to shortcomings both in the housing market valuation standards and in the methodology used in the standards, which does not meet global challenges. The research results on housing heterogeneity as well as the systemic approach to the quantitative and qualitative effects as a result of the interaction among heterogeneity dimensions can be used by the International Valuation Standards Council in order to develop the International Valuation Standards.

The research on housing heterogeneity cannot be considered a complete research in the area of the most important transaction object of the housing market. Rather, it is the beginning of a new approach, which opens up opportunities for a more detailed investigation of the formation of the market value of housing units in order to gain a clearer understanding of the nature and dynamics of price changes of housing units in a constantly changing environment. The research results can be used in managerial decision making by market participants who directly and/or indirectly engage in housing transactions. In this regard, the most important aspect is the improvements necessary to be implemented in the housing market valuation methodology, as well as in the operation of state institutions, which constantly monitor the behaviour of market participants and the events in the market in order to timely and effectively respond to the threats that can cause a sharp rise in prices in the housing market.

\section{REFERENCES}

Agarwal, S., Rengarajan, S., Sing, T. F., \& Yang, Y. (2016). School allocation rules and housing prices: A quasi-experiment with school relocation events in Singapore. Regional Science and Urban Economics, 58, 42-56. https://doi.org/10.1016/j.regsciurbeco.2016.02.003

Aladdinovna, A. (2016). Correlation between corruption and economic crimes in housing and communal services. Ekonomika, 62(2), 15-28. https://doi.org/10.5937/ekonomika1602015a

De Ayala, A., Galarraga, I., \& Spadaro, J. V. (2016). The price of energy efficiency in the Spanish housing market. Energy Policy, 94, 16-24. https://doi.org/10.1016/j.enpol.2016.03.032 
Balta-Ozkan, N., Boteler, B., \& Amerighi, O. (2014). European smart home market development: Public views on technical and economic aspects across the United Kingdom, Germany and Italy. Energy Research \& Social Science, 3, 65-77. https://doi.org/10.1016/j.erss.2014.07.007

Castellano, J., Ribera, A., \& Ciurana, J. (2016). Integrated system approach to evaluate social, environmental and economics impacts of buildings for users of housings. Energy and Buildings, 123, 106-118. https://doi.org/10.1016/j.enbuild.2016.04.046

Cervero, R., \& Duncan, M. (2004). Neighbourhood composition and residential land prices: does exclusion raise or lower values? Urban Studies, 41(2), 299-315. https://doi.org/10.1080/0042098032000165262

Clapham, D., Franklin, B., \& Saugères, L. (2000). Housing Management: The social construction of an occupational role. Housing, Theory and Society, 17(2), 68-82. https://doi.org/10.1080/140360900457740

Claudy, M., \& Michelsen, C. (2016). Housing Market Fundamentals, Housing Quality and Energy Consumption: Evidence from Germany. The Energy Journal, 37(4), 25-43. https://doi.org/10.5547/01956574.37.4.mcla

Daud, N. (2015). Real Estate Education: Taking Needs and Issues into Consideration. Articles of $7^{\text {th }}$ WAVO Valuation Congress $\left(12^{\text {th }}-13^{\text {th }}\right.$ November 2015. Beijing. China. Retrieved October 10 , 2016, from http://www.wavoglobal.org

Dezhi, L., Yanchao, C., Hongxia, C., Kai, G., Chi-Man Hui, E., \& Yang, J. (2016). Assessing the integrated sustainability of a public rental housing project from the perspective of complex ecosystem. Habitat International, 53, 546-555. https://doi.org/10.1016/j.habitatint.2016.01.001

Gao, L. W., \& Ho, D. C. W. (2016). Explaining the outcomes of multi-owned housing management: A collective action perspective. Habitat International, 57, 233-241. https://doi.org/10.1016/j.habitatint.2016.08.005

Gao, W., \& Chen, G.-Z. (2016). Does owner heterogeneity matter in the management of multiowned housing? Habitat International, 53, 106-114. https://doi.org/10.1016/j.habitatint.2015.11.015

Garth, D. (2006). Crime, Neighborhood, and Public Housing. New York: LFB Scholarly Publishing LLC. ISBN: 1-59332-144-9

Geipele, S., \& Slava, D. (2012). Legal and economic problems of housing management in Latvia. Economics and Business, 22, 144-153.

Gustavsson, E., \& Elander, I. (2016). Sustainability potential of a redevelopment initiative in Swedish public housing: The ambiguous role of residents' participation and place identity. Progress in Planning, 103, 1-25. https://doi.org/10.1016/j.progress.2014.10.003

Hanlon, J. (2014). Fair Housing Policy and the Abandonment of Public Housing Desegregation. Housing Studies, 30(1), 78-99. https://doi.org/10.1080/02673037.2014.933781

Haurin, D. R., \& Brasington, D. (1996). School Quality and Real House Prices: Inter- and Intrametropolitan Effects. Journal of Housing Economics, 5(4), 351-368. https://doi.org/10.1006/jhec.1996.0018

Heitel, S., Kämpf-Dern, A., \& Pfnür, A. (2015). Integration of stakeholder interests in housing companies' strategic management. Property Management, 33(3), 224-244. https://doi.org/10.1108/pm-05-2014-0026

Heijden, H. (2013). West European housing system in a comparative perspective. Amsterdam: IOS Press BV. ISBN: 978-1-61499-194-6

Hernández, D. (2016). Affording Housing at the Expense of Health. Journal of Family Issues, 37(7), 921-946. https://doi.org/10.1177/0192513x14530970

Huh, S., \& Kwak, S.-J. (1997). The Choice of Functional Form and Variables in the Hedonic Price Model in Seoul. Urban Studies, 34(7), 989-998. https://doi.org/10.1080/0042098975691

Koopman, M. J. (2012). Economic Analysis of Neighborhood Quality, Neighborhood Reputation and The Housing Market. Sustainable Urban Areas. Vol. 44. Amsterdam: IOS Press BV. ISBN: 9781614990338

Kurlat, P., \& Stroebel, J. (2015). Testing for Information Asymmetries in Real Estate Markets. Review of Financial Studies, 28(8), 2429-2461. https://doi.org/10.1093/rfs/hhv028

Lindbergh, L., \& Wilson, T. L. (2016). Strategic management in Swedish municipal housing. Property Management, 34(2), 136-157. https://doi.org/10.1108/pm-07-2015-0030 
O’Sullivan, T., \& Gibb, K. (2008). Housing Economics and Public Policy. Oxford, UK: Blackwell Science Ltd. https://doi.org/10.1002/9780470690680

Osland, L., Thorsen, I. S., \& Thorsen, I. (2016). Accounding for Local Spatial Heterogeneities in Housing Market Studies. Journal of Regional Science, 56(5), 895-920. https://doi.org/10.1111/jors.12281

Parker, D. (2016). International Valuation Standards: A Guide to the Valuation of Real Property Assets, Oxford, UK: Wiley-Blackwell. https://doi.org/10.1002/9781118329795

Peterson, N. M., Peterson, T. R., \& Jianguo, L. (2013). The Housing Bomb: Why Our Addiction to Houses Is Destroying the Environment and Threatening Our Society. Baltimore: Johns Hopkins University Press. ISBN-13: 978-1-4214-1065-4.

Posey, S. (2016). The Roots of the Modern Housing Crisis. New Politics, 15(4), 40-42.

Reed, R. R., \& Ume, E. S. (2016). Housing and unemployment: The search for the "American Dream." Journal of Macroeconomics, 48, 72-86. https://doi.org/10.1016/j.jmacro.2016.01.001

Rosen, S. (1974). Hedonic Prices and Implicit Markets: Product Differentiation in Pure Competition. Journal of Political Economy, 82(1), 34-55. https://doi.org/10.1086/260169

Rubio, M. (2014). Housing-market heterogeneity in a monetary union. Journal of International Money and Finance, 40, 163-184. https://doi.org/10.1016/j.jimonfin.2013.06.013

Seinre, E., Kurnitski, J., \& Voll, H. (2014). Quantification of environmental and economic impacts for main categories of building labeling schemes. Energy and Buildings, 70, 145-158. https://doi.org/10.1016/j.enbuild.2013.11.048

Swinkoski, A. (2012). Troubled affordable housing: bridging the gap. Journal of Property Management, 77(1), 16-20. ISSN: 1755-2478.

Voborníková, P. (2014). Divided We Live: Racial and Ethnic Segregation in Housing in the U.S. The Scientific Journal of Humanistic Studies, 6(10), 43-51. ISSN 2066-8880.

Wen, X.-C., \& He, L.-Y. (2015). Housing demand or money supply? A new Keynesian dynamic stochastic general equilibrium model on China's housing market fluctuations. Physica A: Statistical Mechanics and Its Applications. 432, 257-268. https://doi.org/10.1016/j.physa.2015.03.040

White, L. J. (2016). Housing Policy, The Morning After. Milken Institute Review: A Journal of Economic Policy. 64-78. ISSN: 033-5533.

Whittaker, E., Flatau, P. R., Swift, W., Dobbins, T. A., \& Burns, L. (2016). Associations of Housing First Configuration and Crime and Social Connectedness Among Persons With Chronic Homelessness Histories. Psychiatric Services, 67(10), 1091-1097. https://doi.org/10.1176/appi.ps.201500446

Yau, Y. (2012). Willingness to participate in collective action: the case of multiowned housing management. Journal of Urban Affairs, 35(2), 153-171. https://doi.org/10.1111/j.1467-9906.2012.00621.x

\section{AUTHORS' SHORT BIOGRAPHIES}

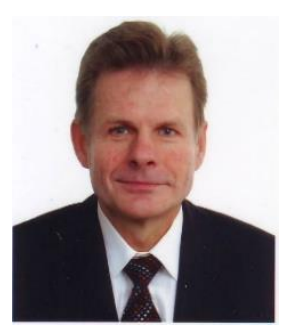

Jānis Vanags is a Professor of the Faculty of Engineering Economics and Management at Riga Technical University (RTU). He received the Doctoral degree in economics from RTU in 2004.

His research and teaching interests include national economics, engineering economics, building management, real estate economics, microeconomics and macroeconomics processes, real estate management, and sustainable development. At present, J. Vanags teaches undergraduate and postgraduate courses in national economics, finance market, and real estate economics at RTU. 


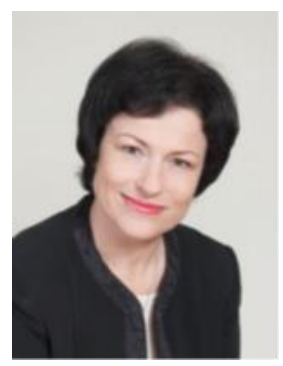

Ineta Geipele is a Professor of the Faculty of Engineering Economics and Management, Director of the Institute of Civil Engineering and Real Estate Economics, the Head of the Department of the Civil Construction and Real Estate Economics and Management at Riga Technical University, Latvia. She improved her professional skills in Austria, Germany, Denmark and the UK. Ineta Geipele is the author and co-author of more than 300 scientific publications. Her current research areas are sustainability development problems of real estate market, construction industry, land use management and institutional economics. Professor Ineta Geipele is an expert of the Latvian Academy of Sciences in Management and Economics Sciences at the Latvian Council of Science, a board member of the FIABCI-Baltic Multinational Chapter and of the Cunfte of the Facility Management of Latvian Housing, and a member of the Latvian Union of Civil Engineers.

ORCID iD: http://orcid.org/0000-0002-2963-087X

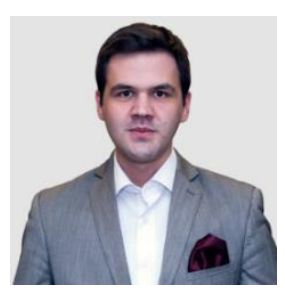

Auseklis Sarkans received the Academic Bachelor's degree in business and economics from Stockholm School of Economics in Riga (SSE Riga) and the Professional Master's degree in civil construction and real estate management from Riga Technical University (RTU). At present, A. Sarkans is leading the Real Estate Investment Consultation Agency "Verus Investment" (verus.lv) and the Full-service Digital Agency "Austra Agency" (austra.agency). His research interests include real estate development, urban planning and city development, sustainable economic development of cities, big data analytics of real estate, and IT possibilities for real estate industry.

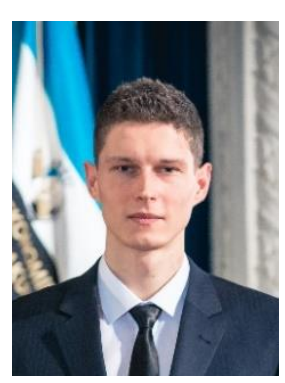

Didzis Usenieks received the Professional Bachelor's degree in real estate management from the Faculty of Engineering and Management of Riga Technical University (RTU). He is currently a Master's degree student of the Professional Master's degree program "Civil Construction and Real Estate Management" at the Faculty of Engineering and Management of RTU. Since 2014, D. Usenieks has been a Certified Assistant to a Real Estate Evaluator of the Latvian Association of Property Appraisers. His research and professional interests include civil construction, real estate management, and real estate market. 